\title{
VARIABILIDADE DE RpoS ENTRE GENÓTIPOS DE Escherichia coli PRODUTORA DE TOXINAS SHIGA (STEC)
}

\author{
VARIABILITY OF RpoS IN SHIGA-LIKE TOXIN-PRODUCING \\ Escherichia coli (STEC)
}

A. E. STELLA ${ }^{1 *}$, B. SPIRA ${ }^{2}$

\section{RESUMO}

Objetivos: RpoS contribui para a virulência através do esforço de sobrevivência contra os sistemas de defesa do hospedeiro, ou diretamente através da regulação de fatores de virulência em certos patógenos. A capacidade dos agentes patogênicos causadores de doenças alimentares sobreviver em certos alimentos depende, principalmente, de seus mecanismos de resposta ao estresse. Neste sentido foi objetivo deste estudo avaliar a variabilidade da produção de RpoS em isolados STEC de diferentes perfis stx ${ }^{+}$. Material e Métodos: Foi avaliada a produção de RpoS em 31 cepas, 8 cepas stx2, 16 cepas $s t x l+s t x 2$ e 7 cepas stxl. O lisado de células foi resolvido em gel de acrilamida, e após a eletroforese, as proteínas foram transferidas a uma membrana de nitrocelulose submetida a ensaio de imuno-detecção com o soro antiRpoS e soro anti-IgG conjugado. Para detecção do complexo, foi utilizado kit de deteç̧ão e a membrana exposta a filmes de raios-X. Resultados: Não observamos diferenças significativas no nível de produção de RpoS entre os perfis stx1 e stx2. O perfil stx1+ stx2 produziu, em geral, níveis menores de RpoS do que os dois perfis anteriores, mas nenhuma era rpoS-negativa. Avaliar o nível de produção de RpoS nos isolados STEC é fundamental pois já foi demonstrada sua importância para a E. coli O157:H7 sobreviver sob alta pressão hidrostática, em solo adubado com esterco, em água filtrada de lago, bem como em ambientes ácidos e na excreção pelos bezerros. Contudo, a perda da função de RpoS em E. coli O157:H7 é conhecida por desreprimir a expressão de alguns genes de virulência e de aumentar a formação de biofilme e colonização do intestino do hospedeiro devido ao aumento da capacidade metabólica em mutantes. Conclusão: A produção de RpoS foi expressa heterogeneamente na população das STEC avaliadas, isto provavelmente reflete um esforço de adaptação ambiental.

PALAVRAS-CHAVE: SIGMA S. ESTRESSE. VIRULÊNCIA.

AGRADECIMENTOS: FAPESP

ÁREA TEMÁTICA: Doenças Infecciosas 